\title{
Analiza cech geometrycznych powierzchni po cięciu hydroabrazywnym konstrukcji przekładkowych
}

\author{
Analysis of geometric features of the surface \\ after hydro-abrasive cutting of sandwich structure
}

\section{Streszczenie}

W pracy przedstawiono wybrane wyniki badań jakości powierzchni po cięciu strugą wodno-ścierną próbek złożonych z kilku warstw materiałów klejonych klejem epoksydowym. Takie konstrukcje przekładkowe wykonano ze stopu tytanu Ti6Al4V, stopu aluminium AW2017A oraz kompozytu epoksydowo-węglowego. Badane materiały klejono w układzie "sandwich" w różnej konfiguracji. Proces cięcia realizowano z użyciem technologii „waterjet” ze zmienną prędkością posuwu vf. Analizowano wybrane parametry chropowatości (2D oraz 3D) powstałej po cięciu powierzchni, parametry chropowatości powierzchni w strefie wejścia oraz wyjścia strugi wodno-ściernej, przedstawiono topografię powstałej powierzchni oraz kąt ukosowania powierzchni po cięciu. Pracę zakończono wnioskami.

Słowa kluczowe: cięcie hydroabrazywne; połączenia klejowe; warstwa wierzchnia

\section{Abstract}

The paper presents selected results of the surface quality measurements after hydro-abrasive cutting the samples bonded using different epoxy adhesives. Such sandwich structures are made of Ti6Al4V titanium alloy, AW2017A aluminum alloy and carbon composite. The test materials were bonded in a "sandwich" in various configurations. The cutting process was realized with the use of "waterjet" technology under variable speed vf. Analyzed selected roughness parameters (2D and $3 D$ ) formed on the cutting surface, surface roughness parameters are input and output waterjet abrasive, the resulting surface topography is shown and the angle of the bevel surface after cutting. Conclusions from the tests are presented at the final stage of the paper.

Keywords: abrasive water jet; adhesive joints; surface layer

\section{Wstęp}

Cięcie hydroabrazywne rozwija się w szybkim tempie, zalety tej technologii są powszechnie znane. Technologia jest nowa, stąd obserwuje się wiele prac naukowo-badawczych podejmujących to zagadnienie w aspekcie badań o charakterze zarówno ogólnym jak i aplikacyjnym. W przypadku cięcia hydroabrazywnego materiałów jednorodnych sytuacja jest stosunkowo prosta [1], struga napotyka na materiał o określonych właściwościach i zjawiska związane z zachowaniem sie strugi zależą $\mathrm{w}$ największym stopniu od cech fizycznych tego materiału [2:9]. W sytuacji konstrukcji złożonych z materiałów o istotnie różniących się cechach fizycznych sytuacja jest bardzie skomplikowana i efekty jakościowe powierzchni przecięcia struktur przekładkowych są uzależnione od cech fizycznych materiałów składowych.

Celem pracy było określenie cech geometrycznych powierzchni po cięciu strugą wodno-ścierną konstrukcji przekładkowych, szczególnie w aspekcie różnic tych cech w strefach łączenia materiałów. W pracy analizie poddano konstrukcje klejone dwoma klejami istotnie różniącymi się sztywnością. Przedstawiono niektóre wyniki badań jakości powierzchni przecięcia strugą wodno-ścierną konstrukcji przekładkowych, metalowo-polimerowych.

\section{Metodyka badań}

Podczas badań wykorzystano próbki wykonane ze stopu aluminium AW2017A o grubości $2 \mathrm{~mm}$, próbki o grubości 1,6 $\mathrm{mm}$ wykonane ze stopu tytanu Ti6Al4V oraz próbki z kompozytu węglowego o grubości $2 \mathrm{~mm}$, szerokość próbek wynosiła $20 \mathrm{~mm}$, natomiast długość $100 \mathrm{~mm}$. Przygotowane próbki klejono wykorzystując klej Hysol 9466 oraz klej Hysol 9484. Proces przygotowania powierzchni pod klejenie stopu aluminium oraz stopu tytanu polegał na obróbce ściernej (szlifierka oscylacyjna), szlifowaniem włókniną

Dr inż. Mariusz Kłonica, prof. dr hab. inż. Józef Kuczmaszewski - Politechnika Lubelska.

Autor korespondencyjny/Corresponding author. m.klonica@pollub.pl 
P80 oraz trzykrotnym odtłuszczeniu powierzchni obrobionej środkiem odtłuszczającym Loctite 7063. Proces klejenia przebiegał $w$ temperaturze otoczenia wynoszącej $21-24^{\circ} \mathrm{C}$. Czas utwardzania ustalono na stałym poziomie 168 godzin. W tablicy I zestawiono warianty przygotowanych próbek.

Tablica I. Warianty przygotowania próbek

Table I. Variants sample preparation

\begin{tabular}{|c|c|}
\hline Wariant & Materiał oraz klej \\
\hline $\mathrm{T} 1$ & $\begin{array}{c}\text { AW2017A-Kompozyt węglowy-AW2017A-klej } \\
\text { Hysol } 9466\end{array}$ \\
\hline T2 & $\begin{array}{c}\text { AW2017A-Kompozyt węglowy-AW2017A-klej } \\
\text { Hysol } 9484\end{array}$ \\
\hline T3 & $\begin{array}{c}\text { Ti6Al4V-Kompozyt węglowy-Ti6Al4V-klej } \\
\text { Hysol } 9466\end{array}$ \\
\hline $\mathrm{T} 4$ & $\begin{array}{c}\text { Ti6Al4V-Kompozyt węglowy-Ti6Al4V-klej } \\
\text { Hysol } 9484\end{array}$ \\
\hline
\end{tabular}

Rejestrację wybranych parametrów chropowatości powierzchni oraz skanowanie powierzchni przeprowadzono na urządzeniu do pomiaru konturu, chropowatości i topografii 3D T8000 RC-120-400 firmy Hommel-Etamic. Długość odcinka elementarnego dobrano na podstawie literatury [7 $\div 12$ ]. Analizie poddano dwa parametry chropowatości powierzchni: Ra - średnia arytmetyczna rzędnych profilu chropowatości oraz Rt - całkowita wysokość profilu chropowatości. Przecinanie badanych próbek klejonych zrealizowano z wykorzystaniem technologii cięcia hydroabrazywnego na urządzeniu firmy Eckert o nazwie Opal Waterjet Combo. Prędkość posuwu podczas badań wynosiła 150 oraz $700 \mathrm{~mm} /$ minutę. Ciśnienie strugi ustalono na poziomie $350 \mathrm{MPa}$, a wydatek ścierniwa (Garnet 80 Mesh) na poziomie 4,6 kg/min. W badaniach wykorzystano również mikroskop Keyence VHX-5000 w celu obrazowania i pomiarów kąta ukosowania powierzchni powstałej wskutek cięcia strugą wodno-ścierną.

\section{Wyniki badań}

$\mathrm{Na}$ rysunku 1 przedstawiono fotografię powierzchni struktury przekładkowej dla wariantu T1 po cięciu próbki strugą wodno-ścierną.

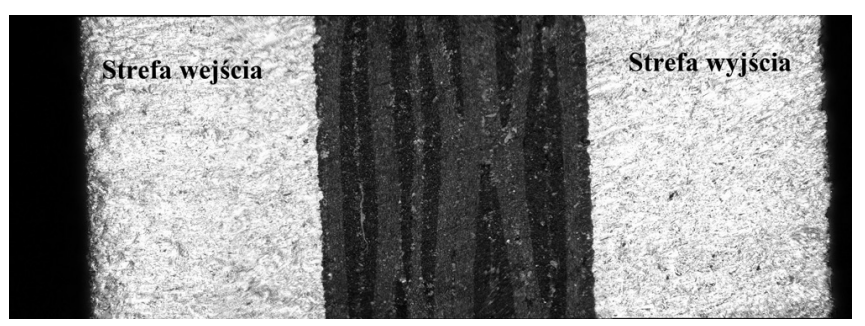

Rys. 1. Powierzchnia próbki - wariant $\mathrm{T} 1$, po cięciu strugą wodnościerną $\mathrm{z} v \mathrm{vf}=700 \mathrm{~mm} / \mathrm{min}$

Fig. 1. The surface of samples - variant $\mathrm{T} 1$ after cutting jet of water and abrasive at $\mathrm{vf}=700 \mathrm{~mm} / \mathrm{min}$

$\mathrm{Na}$ prezentowanej fotografii można dostrzec wyraźne różnice $\mathrm{w}$ topografii $\mathrm{w}$ strefie wejścia oraz wyjścia strugi wodno-ściernej. Próbka została wykonana w wariancie T1, a prędkość cięcia wynosiła $v f=700 \mathrm{~mm} / \mathrm{min}$. Nie widać istotnych zmian cech geometrycznych w obszarze sklejenia, a jedynie różnice cech geometrycznych w obszarze wejścia i wyjścia strugi.
W tablicy II zestawiono widoki izometryczne powierzchni powstałej po cięciu strugą wodno-ścierną badanych próbek. Literą A - oznaczono strefę wejścia strugi wodno-ściernej, natomiast literką B - strefę wyjścia. Na prezentowanych widokach izometrycznych topografii powierzchni można dostrzec wyraźnie ugięte prążki w strefie wyjścia strugi wodno-ściernej.

Strefa wejścia strugi wodno-ściernej charakteryzuje się jednorodną strukturą o niższych parametrach chropowatości powierzchni w stosunku do strefy wyjścia strugi wodno-ściernej. Na przedstawionych mapach topografii powierzchni można zauważyć typowe dla obróbki hydroabrazywnej ślady powstałe na powierzchni przecinanych konstrukcji przekładkowych. Na rysunkach 2 oraz 3 przedstawiono wpływ rodzaju materiału próbek przecinanych oraz prędkości posuwu na wartość wybranych parametrów chropowatości powierzchni (Ra oraz Rt) w strefie wejścia i wyjścia. Na rysunku 2 przedstawiono parametr chropowatości powierzchni Ra, natomiast na rysunku 3 parametr Rt chropowatości powierzchni. Jako miarę rozrzutu uzyskanych wyników podano wartość odchylenia standardowego. Po przeprowadzonych badaniach stwierdzono wzrost wartości parametru Ra chropowatości powierzchni w strefie wyjścia w stosunku do wartości tego parametru w strefie wejścia. Wzrost ten obserwowany jest zarówno dla powierzchni powstałych po przecinaniu z prędkością posuwu $150 \mathrm{~mm} / \mathrm{min}$ jak i $700 \mathrm{~mm} / \mathrm{min}$.

\section{a) $\quad$ Strefa wejścia $\quad$ Strefa wyjścia}

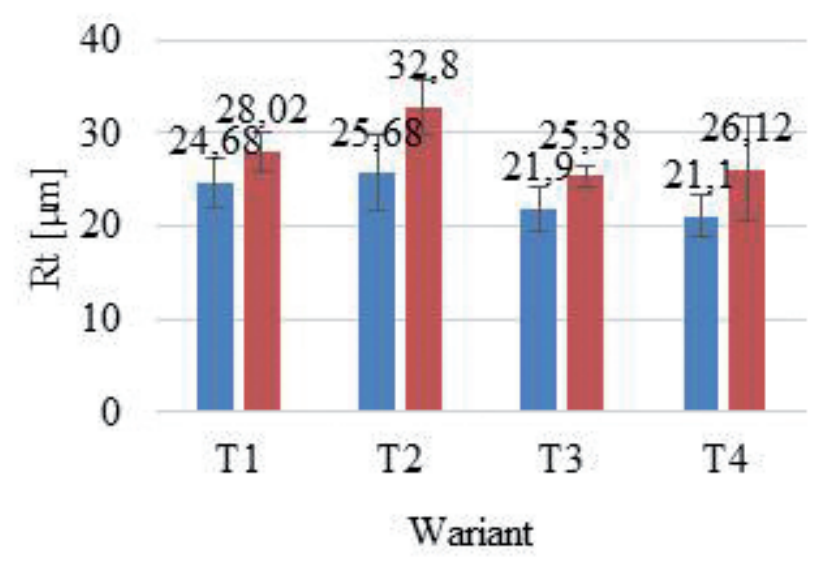

b) $\quad$ Strefa wejścia $\quad$ Strefa wyjścia

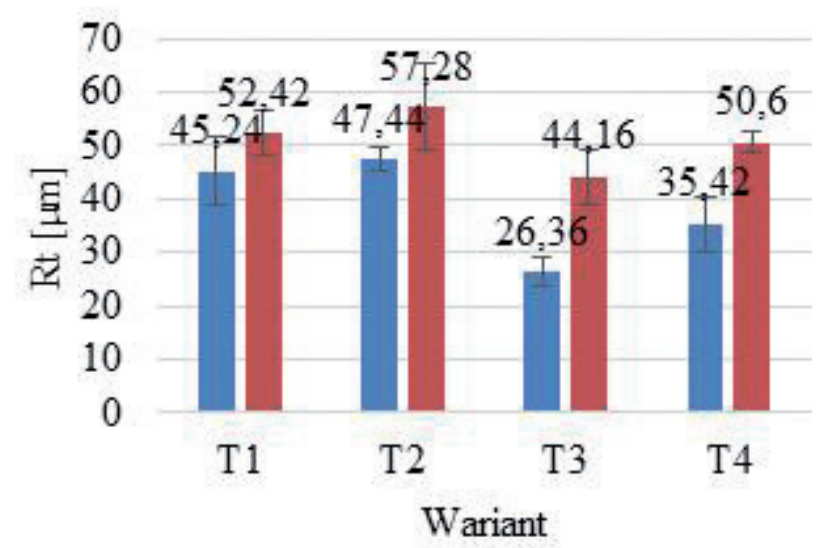

Rys. 2. Parametr Ra chropowatości powierzchni po cięciu próbki w strefie wejścia i wyjścia: a) prędkość cięcia $v_{f}=150 \mathrm{~mm} / \mathrm{min}$, b) prędkość cięcia $\mathrm{v}_{\mathrm{f}}=700 \mathrm{~mm} / \mathrm{min}$

Fig. 2. The Ra surface roughness parameter samples after cutting in input and output zone: a) cutting speed $\mathrm{v}_{\mathrm{f}}=150 \mathrm{~mm} / \mathrm{min}, \mathrm{b}$ ) cutting speed $\mathrm{v}_{\mathrm{f}}=700 \mathrm{~mm} / \mathrm{min}$ 


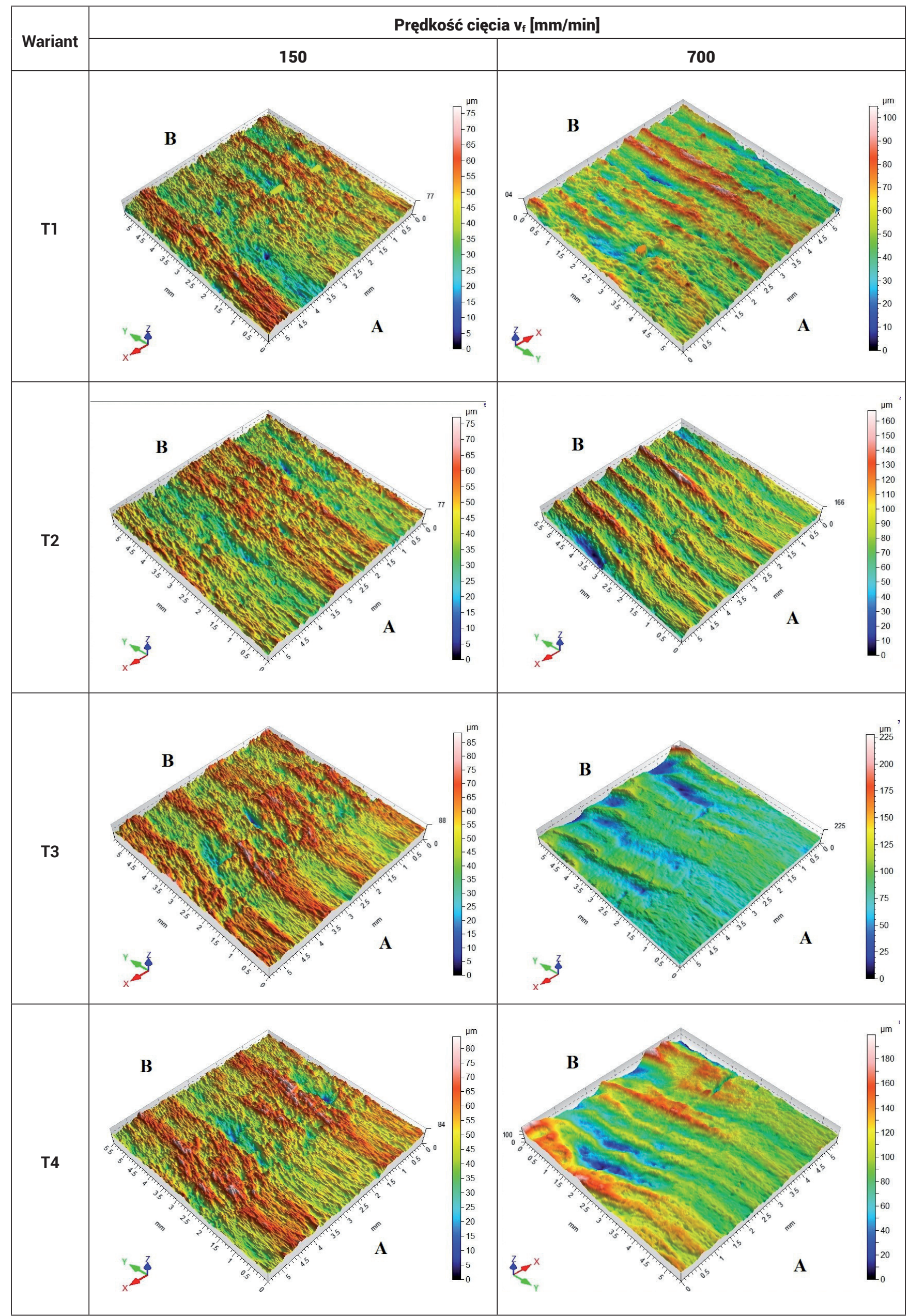


Strefa wejścia $\quad$ Strefa wyjścia

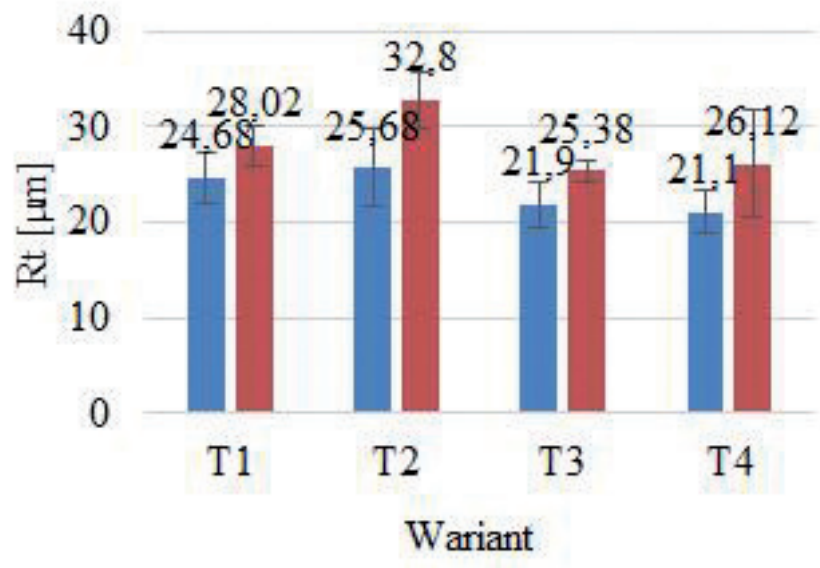

— Strefa wejścia $\quad$ Strefa wyjścia

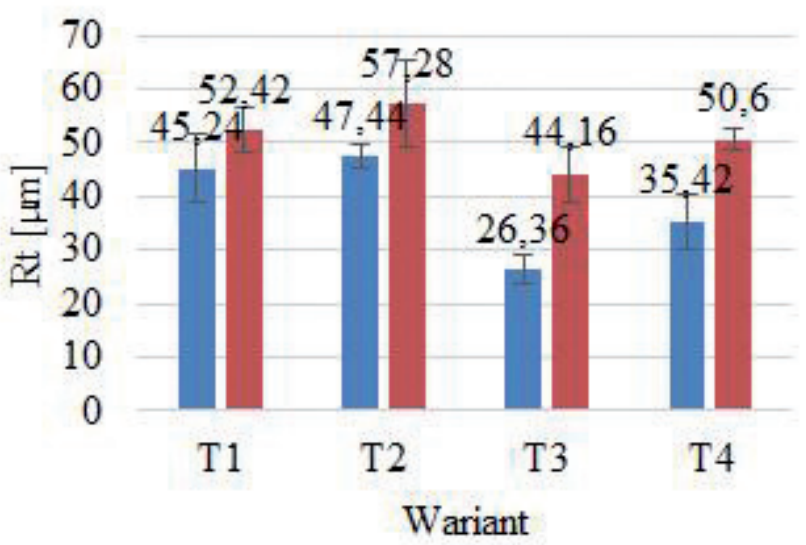

Rys. 3. Parametr Rt chropowatości powierzchni po cięciu próbki w strefie wejścia i wyjścia: a) prędkość cięcia $\mathrm{v}_{\mathrm{f}}=150 \mathrm{~mm} / \mathrm{min}$, b) prędkość cięcia $v_{f}=700 \mathrm{~mm} / \mathrm{min}$

Fig. 3. The Rt surface roughness parameter samples after cutting in input and output zone: a) cutting speed $v_{f}=150 \mathrm{~mm} / \mathrm{min}$, b) cutting speed $v_{f}=700 \mathrm{~mm} / \mathrm{min}$

Największy wzrost wartości parametru Ra w strefie wyjścia w stosunku do strefy wejścia zaobserwowano dla próbek wariantu T3 przecinanych z prędkością posuwu 700 $\mathrm{mm} / \mathrm{min}$ i wynosi on $75 \%$. Najmniejszy wzrost tego parame-

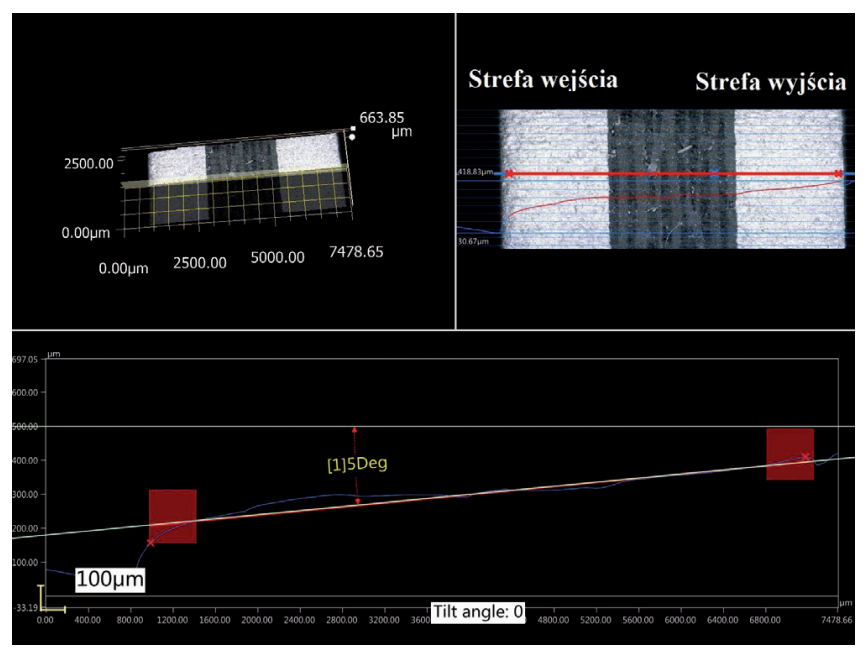

Rys. 4. Kąt ukosowania powierzchni próbki wykonanej w wariancie T1 po cięciu z prędkością vf $=150 \mathrm{~mm} / \mathrm{min}$

Fig. 4. The angle of the bevel surface of the sample made in the variant $\mathrm{T} 1$ after cutting at a speed $\mathrm{vf}=150 \mathrm{~mm} / \mathrm{min}$ tru zanotowano dla próbek wariantu T2 przecinanych z prędkością $150 \mathrm{~mm} / \mathrm{min}$ i wynosił on ok. 9\%. Należy zauważyć istnienie różnicy $\mathrm{w}$ wartościach parametru $\mathrm{Ra} w$ strefach wyjścia w stosunku do strefy wejścia dla prędkości przecinania 700 mm/min i kleju Hysol 9484, a więc kleju o istotnie mniejszej sztywności w stanie utwardzonym w stosunku do kleju Hysol 9466. Obserwacja ta dotyczy zarówno stopu aluminium jak i stopu tytanu.

Również zaobserwowano wzrost parametru Rt w strefie wyjścia strugi wodno-ściernej w stosunku do strefy wejścia. Największy wzrost wartości parametru Rt w strefie wyjścia w stosunku do strefy wejścia zaobserwowano dla próbek wariantu T3 przecinanych z prędkością posuwu $700 \mathrm{~mm} /$ min i wynosi on $67 \%$. Najmniejszy wzrost tego parametru zanotowano dla próbek wariantu T1 przecinanych z prędkością $150 \mathrm{~mm} / \mathrm{min}$ i wynosił on ok. 13\%.

Rysunek 4 przedstawia przykład pomiaru kąta ukosowania powierzchni po cięciu strugą wodno-ścierną, jako przykład przedstawiono próbkę wykonaną w wariancie $\mathrm{T} 1$ po cięciu z prędkością vf=150 $\mathrm{mm} / \mathrm{min}$.

Tylko dla dwóch wariantów T1 oraz T2 zaobserwowano typowy kąt ukosowania powierzchni po cięciu strugą wodno-ścierną z prędkością cięcia $\mathrm{vf}=150 \mathrm{~mm} / \mathrm{min}$. Dla wariantu T1 kąt ten wynosił $5^{\circ}$, natomiast dla wariantu T2 wartość kąta wynosiła $8^{\circ}$. Różnica ta wynika prawdopodobnie z różnych warunków hamowania strugi przy przecinaniu warstwy kleju o niższej sztywności.

$\mathrm{Na}$ rysunku 5 przedstawiono powierzchnię powstałą po cięciu strugą wodno-ścierną próbek wykonanych w wariancie T3 oraz T4 przecinanych z prędkością vf $=150 \mathrm{~mm} / \mathrm{min}$ oraz dla wszystkich wariantów przecinania próbek z prędkością vf=700 mm/min. Na przedstawionym rysunku można zauważyć zmianę ukosowania powstałej powierzchni w materiale o mniejszej twardości jakim jest kompozyt węglowy. Zaznaczona na rysunku 5 strefa ukosowania powierzchni wynosiła od $300 \mu \mathrm{m}$ (T2 - vf=700 mm/min) do $674 \mu \mathrm{m}$ (T4 - vf=700 mm/min).

W tablicy III oraz IV zestawiono wybrane fotografie powierzchni uzyskanych po cięciu strugą wodno-ścierną dla użytych materiałów. Fotografie przedstawione w tablicach zostały wykonane przy powiększeniu 500 razy.

Po przeprowadzonej analizie fotografii nie stwierdzono rozwarstwienia próbek po cięciu strugą wodno-ścierną (z różnymi prędkościami posuwu), co jest korzystne ze względów eksploatacyjnych.

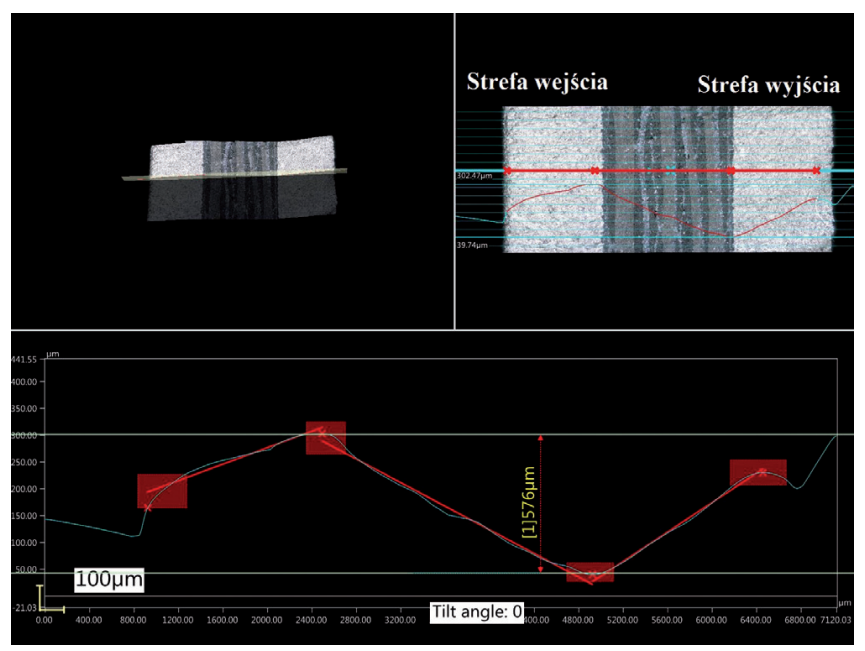

Rys. 5. Powierzchnia próbki po cięciu dla wariantu T3 - vf $=700$ $\mathrm{mm} / \mathrm{min}$

Fig. 5. The sample surface after cutting variant $\mathrm{T} 3-\mathrm{vf}=700$ $\mathrm{mm} / \mathrm{min}$ 
Tablica III. Fotografie powierzchni powstałej po cięciu - klej Hysol 9466

Table III. Photographs of surface formed after cutting - adhesive Hysol 9466

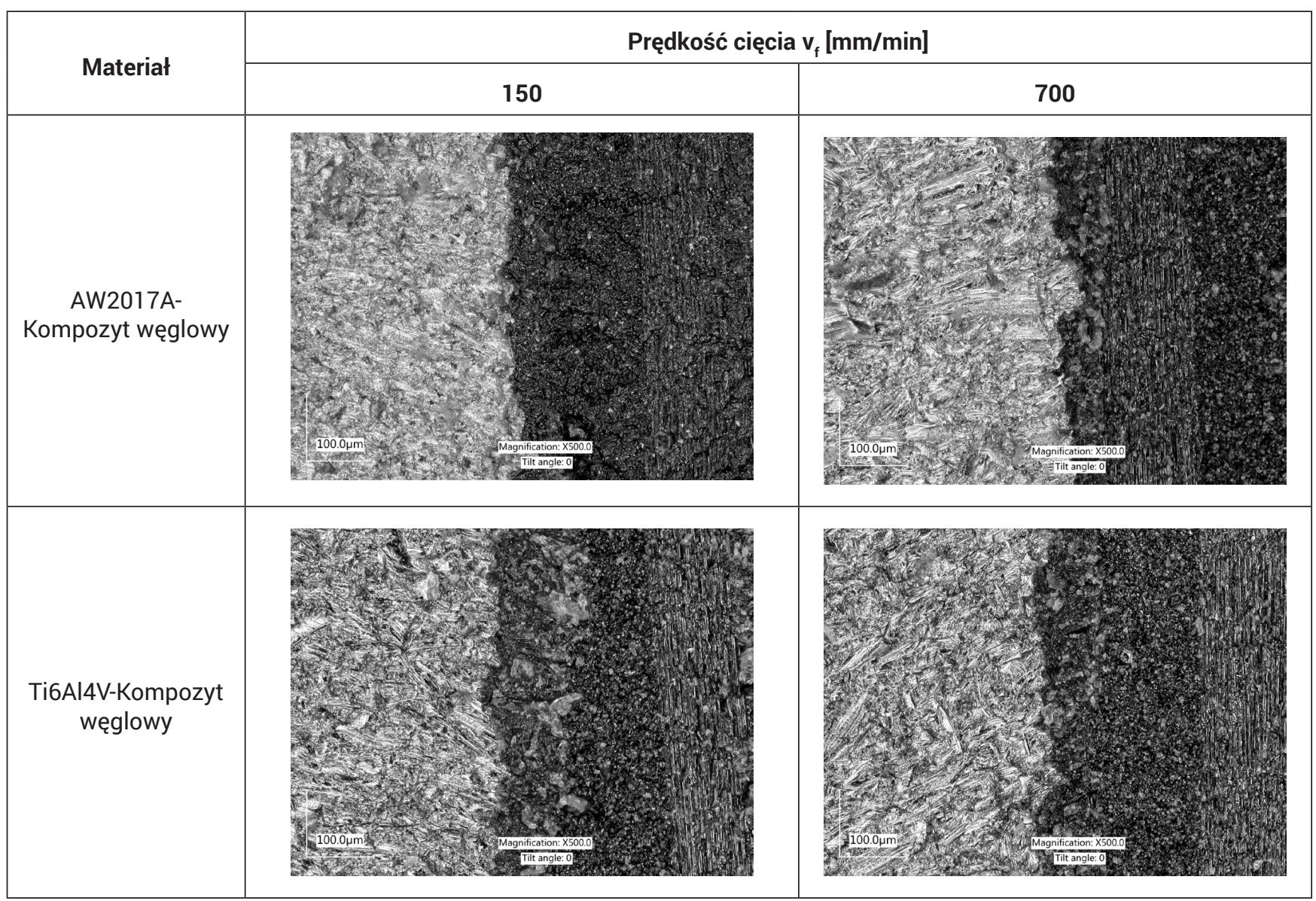

Tablica IV. Fotografie powierzchni powstałej po cięciu - klej Hysol 9484

Table IV. Photographs of surface formed after cutting - adhesive Hysol 9484

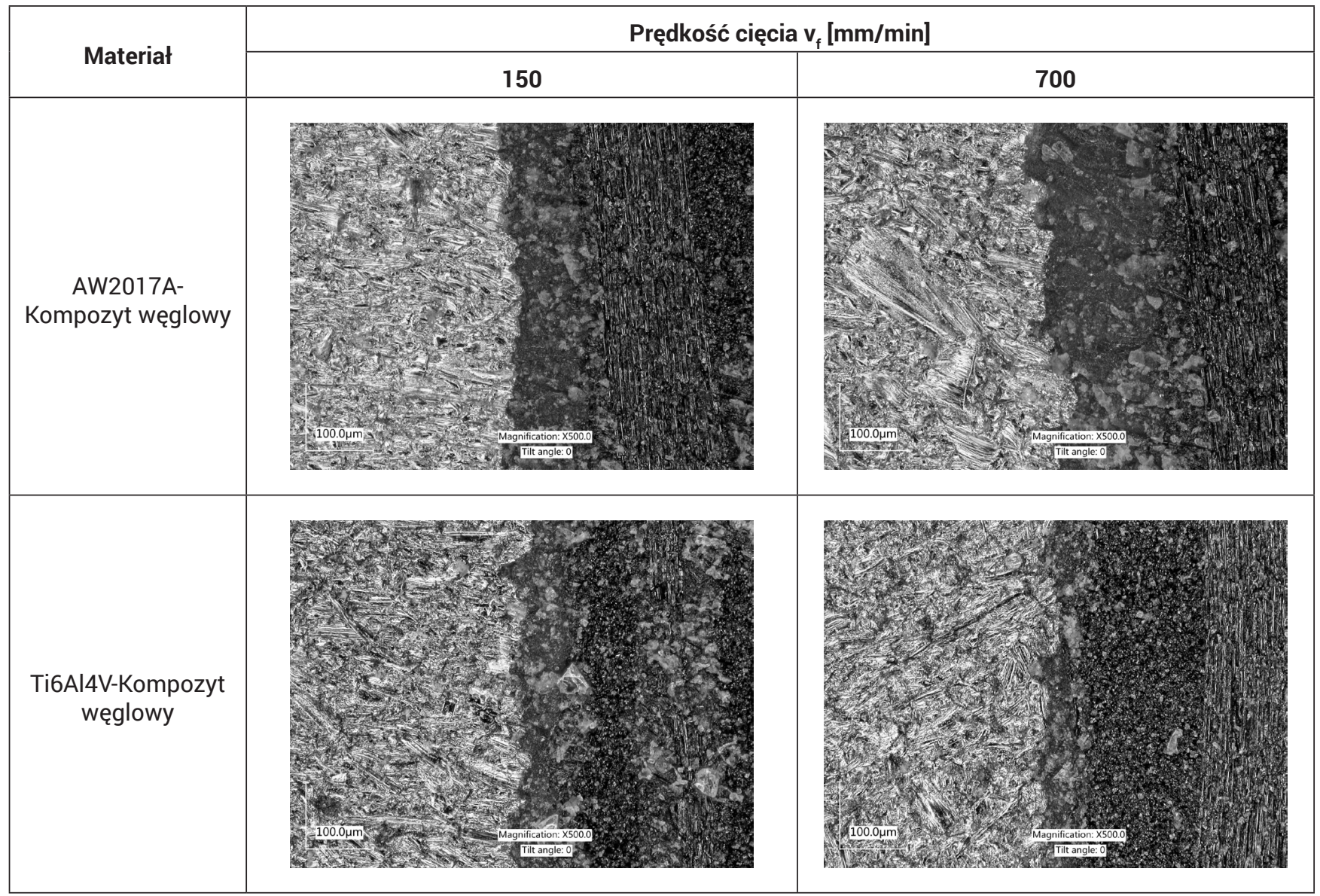




\section{Wnioski}

Na podstawie przeprowadzonych badań można sformułować następujące wnioski o charakterze ogólnym:

1. Po przeprowadzonych badaniach jednoznacznie stwierdzono istotny wpływ prędkości posuwu strugi wodno-ściernej na wartość parametrów chropowatości powierzchni zarówno parametru Ra jak i parametru Rt chropowatości powierzchni konstrukcji przekładkowych.

2. Z badań wynika, że większa różnica parametrów chropowatości powierzchni w strefie wejścia i wyjścia występuje dla konstrukcji sklejanych klejem o mniejszej sztywności. Zaobserwowano to dla prędkości cięcia $700 \mathrm{~mm} / \mathrm{min}$. Jeżeli celem jest zachowanie zbliżonych wartości parametrów chropowatości w strefie wejścia i wyjścia to należy wówczas zmniejszyć prędkość posuwu w procesie cięcia.

3. Kształt powierzchni powstałej w wyniku cięcia strugą wodno-ścierną jest ściśle skorelowany z prędkością cięcia i właściwościami fizycznymi materiałów.

4. Nie stwierdzono rozwarstwień lub innych uszkodzeń w strefie złącza klejowego co rekomenduje tę technologię do przecinania klejowych struktur przekładkowych z udziałem kompozytu węglowego.

\section{Literatura}

[1] M. Kłonica: Analiza powierzchni po cięciu strugą wodno-ścierną klejonych materiałów polimero-wych, Przetwórstwo Tworzyw, nr 2, s. 71-78, 2016.

[2] J. Kuczmaszewski: Fundamentals of metal-metal adhesive joint design, Politechnika Lubelska, Oddział PAN w Lublinie, 2006.

[3] Z. Mirski, R. Wróblewski, A. Gołembiewski: Odporność połączeń klejowych na oddziaływanie wysokiej temperatury, Przegląd Spawalnictwa, Vol 87, No 10, 2015.

[4] M. Kłonica, J. Kuczmaszewski, M. Kwiatkow-ski, J. Ozonek: Polyamide 6 surface layer following ozone treatment, International Journal of Adhesion and Adhesives, 64, s. 179-187, 2016.

[5] J. Pilarczyk, M. S. Węglowski: Wytwarzanie powłok i modyfikacja powierzchni przy użyciu wiązki elektronów w spawalnictwie, Przegląd Spawalnictwa, Vol 87, No 9, 2015.

[6] M. Kwiatkowski, M. Kłonica, J. Kuczmaszewski, S. Satoh: Comparative analysis of energetic properties of Ti6Al4V titanium and EN-AW2017A(PA6) aluminum alloy surface layers for an adhesive bonding application, Ozone-Science \& Engineering, 35, nr 3, s. 220-228, 2013.
[7] M. Blicharski: Inżynieria powierzchni, WNT Warszawa 2009

[8] A. Sajek: Technologia klejenia i właściwości złącza klejowego kompozytowych pian aluminiowych, Przegląd Spawalnictwa, Vol 86, No 3, 2014.

[9] M. Żenkiewicz: Adhezja i modyfikowanie warstw wierzchniej tworzyw wielkocząsteczkowych, WNT, Warszawa 2000.

[10] B. Kamieńska-Krzowska, M. Kłonica: Rola strategii pomiarów topografii powierzchni w ocenie wybranych parametrów chropowatości, Mechanik, nr 8-9, s. 138-145, 2014.

[11] Z. Humienny (red.): Specyfikacje Geometrii Wyrobów (GPS) - wykład dla uczelni technicznych, Oficyna wydawnicza PW, s. 540, 2001.

[12] PN-EN ISO 4287:1999/A1:2010P. Specyfikacje geometrii wyrobów. Struktura geometryczna powierzchni: metoda profilowa. Terminy, definicje i parametry struktury geometrycznej powierzchni. 